\title{
Conceptual Solution of Insulating Materials Within Building Installations
}

\author{
Ing. arch. Pavla VRBOVÁ
}

Tutor: Ing. Lenka Prokopová, Ph.D.; Ústav stavitelství II, Fakulta architektury, České vysoké učení technické v Praze, Česká republika

E-mail address: pavla.vrbova@fa.cvut.cz

\begin{abstract}
The aim of this research is to assess the potential of insulating thinfilm material from hollow glass ceramic microspheres in terms of technical building installations. The right design and realization of technical distributions and their insulation in buildings are important for the efficient management of the energy that is necessary for building operations. The research will evaluate the properties of this insulation material for technical installations and the suitability of using it in practice.
\end{abstract}

KEYWORDS: thin-film coating; thermal insulation; hollow glass-ceramic microspheres; technical building installations

\section{Introduction}

The concept of the design, construction and reconstruction of buildings is increasingly carried on the wave of the philosophy of healthy living. The primary factor in healthy living is the healthy indoor microclimate of buildings, which is related to a number of things. One of them is a well-managed project and the implementation of systems of technical building installations used for the operation of buildings. In order for the entire technical building system to be economical in itself, their thermal insulation must be properly designed and implemented. Otherwise, there would be 
significant heat loss through the pipes to their surroundings, which could further negatively affect the functionality and reliability of the entire system, as well as the fact that possible condensation of water vapor on the outer surface of the pipe, caused by malfunctioning insulation, can cause degradation of surrounding structures and their hygienic defects. We should also not forget the suitability of reducing the surface temperatures of all elements of technical equipment of buildings with regard to the safety of their use.

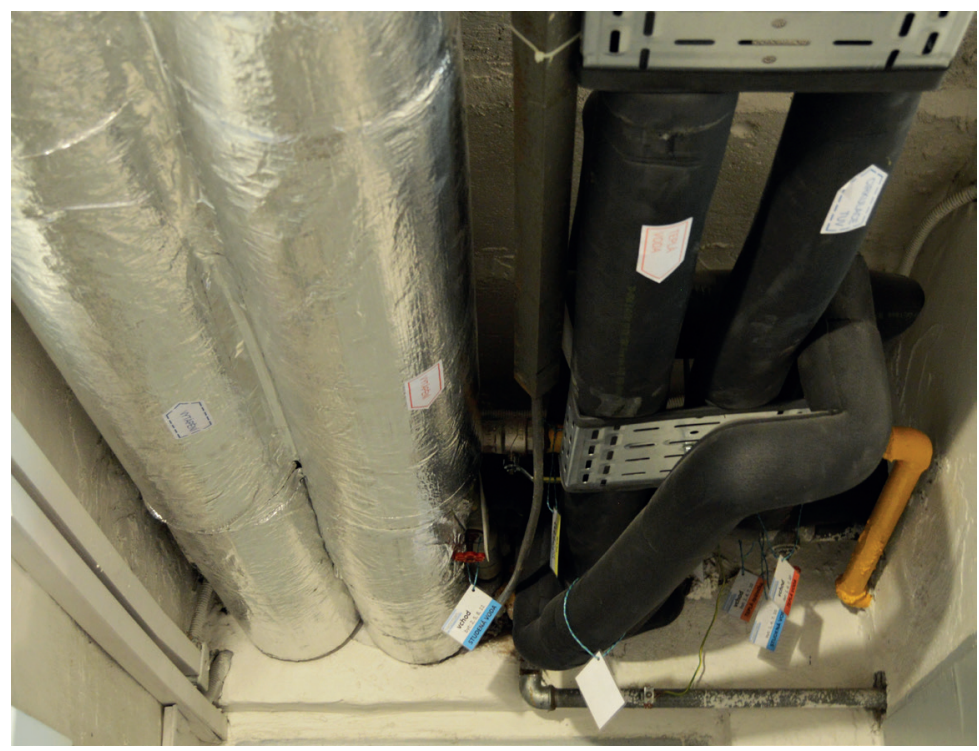

Fig. 1. Common thermal insulation on technical installations (Source: author's photo archive)

\section{Frequent problems from impulse practice for a research project}

The research project aims to reflect the frequent practical problems which are faced by both designers and companies implementing thermal insulation on technical installations, whether it is a solution in new buildings or reconstruction of older buildings. One of the main problems occurring with all buildings is the insulation of more spatially complex distribution routes as well as individual fittings, which often form relatively long sections. In addition, in the reconstruction of distribution systems and the implementation of additional insulation, there is often a fight for every millimetre of space due to the minimum space for additional insulation and its large thickness according to the requirements of Decree No. 193/2007 Coll. and ČSN 75 
5409 [1-2]. The question then, is the overall economic side of the new solution, which is a topic that also surfaces in scientific literature [3]. The solution to these problems is always specific to each object and there are no universal templates for them. Certainly, we should not forget the aesthetics of the overall design, especially in the case of granted wiring installations.

In many situations with traditional insulation materials, it is the case that we are not able to comply with applicable regulations, and it is therefore necessary to look for modern materials that can solve these problems at present.

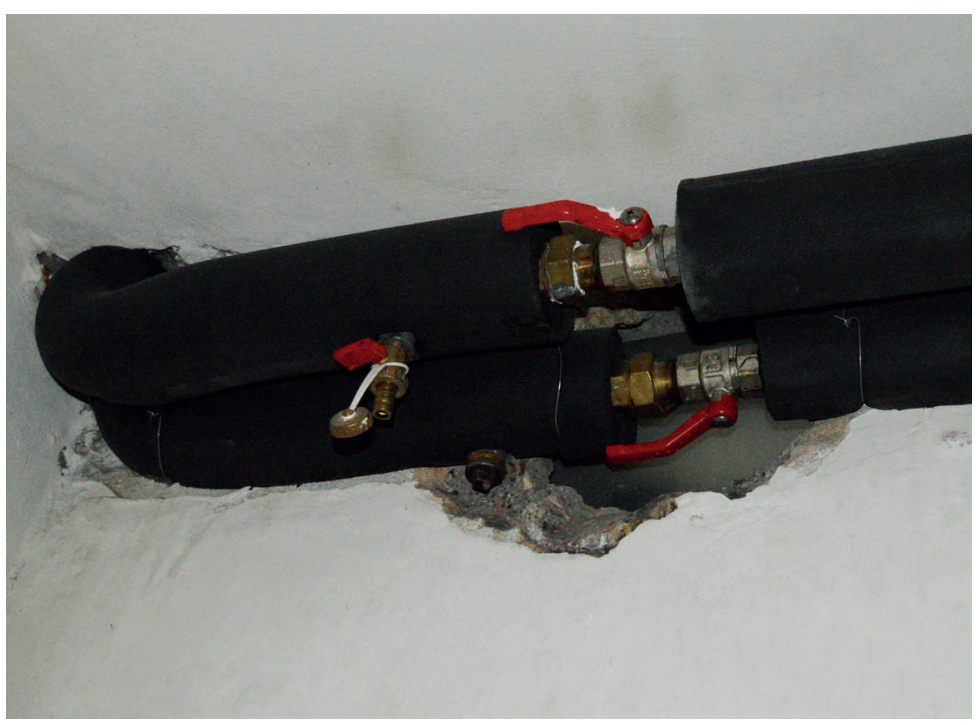

Fig. 2. Insufficient space for additional thermal insulation (Source: author's photo archive)

\section{Investigated modern insulation material}

The American company 3M has been developing a special filler for various materials in the form of hollow glass-ceramic microspheres for several decades. Today, this material is used in a variety of areas from the automotive and aerospace industries to construction.

Hollow glass or ceramic microspheres are particles with a size of 10-100 micrometres and are used in construction, mainly in the form of fillers in the insulating material. Interest in this modern insulation material in the construction industry has grown 
significantly over the last ten years. It is possible to modify the desired properties of the resulting insulating material with various binder additives. This also makes it possible to obtain added value, such as non-vapor permeability, non-flammability, anti-corrosion effects and others, which are required in technical distributions.

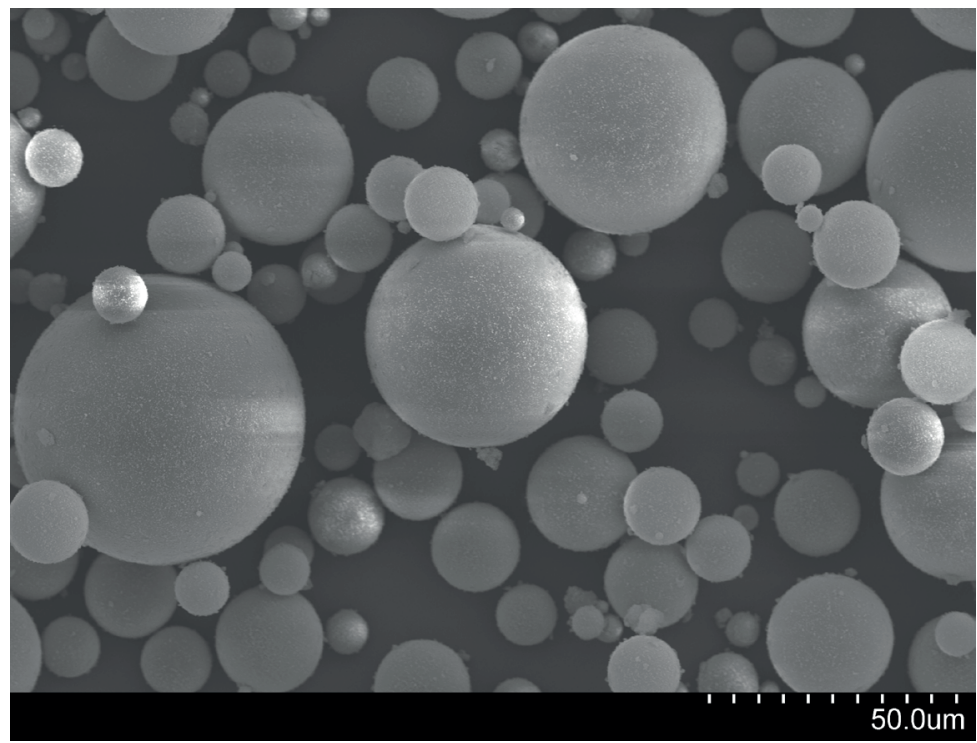

Fig. 3. Hollow glass microspheres under microscope (Source: www.undermisroscope. com)

in the transfer of thermal energy. In addition, the advantage over other established insulation materials is the combination of the reflection of radiant thermal energy, which occurs due to the difference in refractive indices of the binder and filler [4-6].

This insulating material is applied in the form of paint or spray and its great advantage is its thickness in the order of millimetres, which can solve problems with insufficient space for thermal insulation in the reconstruction of wiring. This thermal insulation coating / spray is well adhering to its substrate and thus adaptable in shape. Therefore, even more complex shapes of fittings, through which heat escapes, as well as pipes, are well insulated. A continuous thermal insulation material without joints or any interruptions is created. 


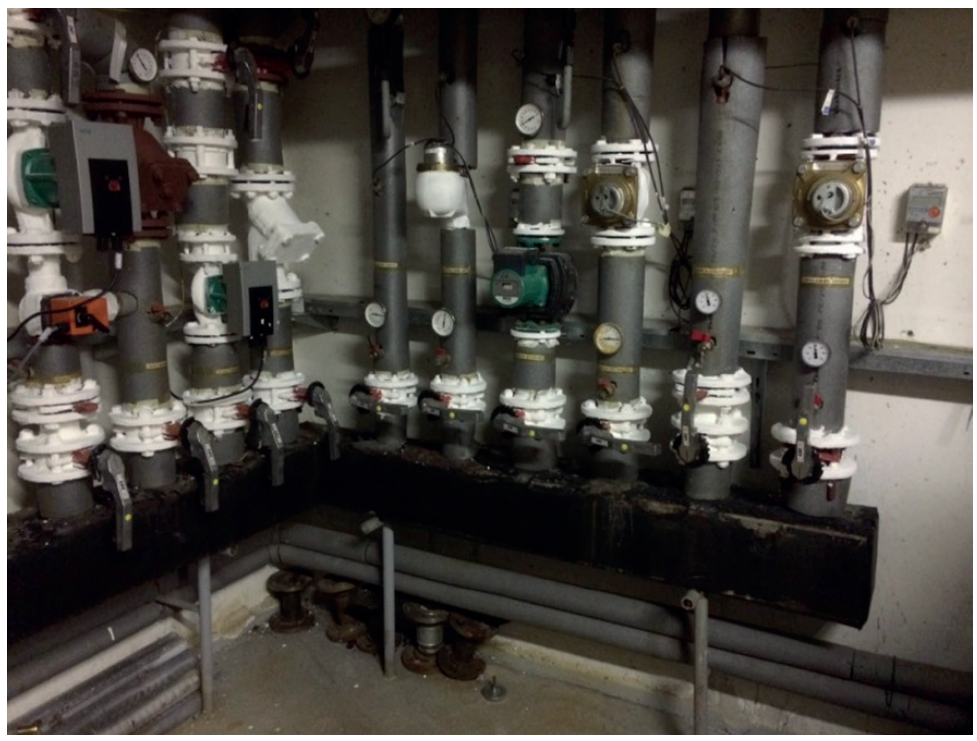

Fig. 4. Additional insulation of fittings (Source: photo archive of the Aditex, spol. s r. o., company)

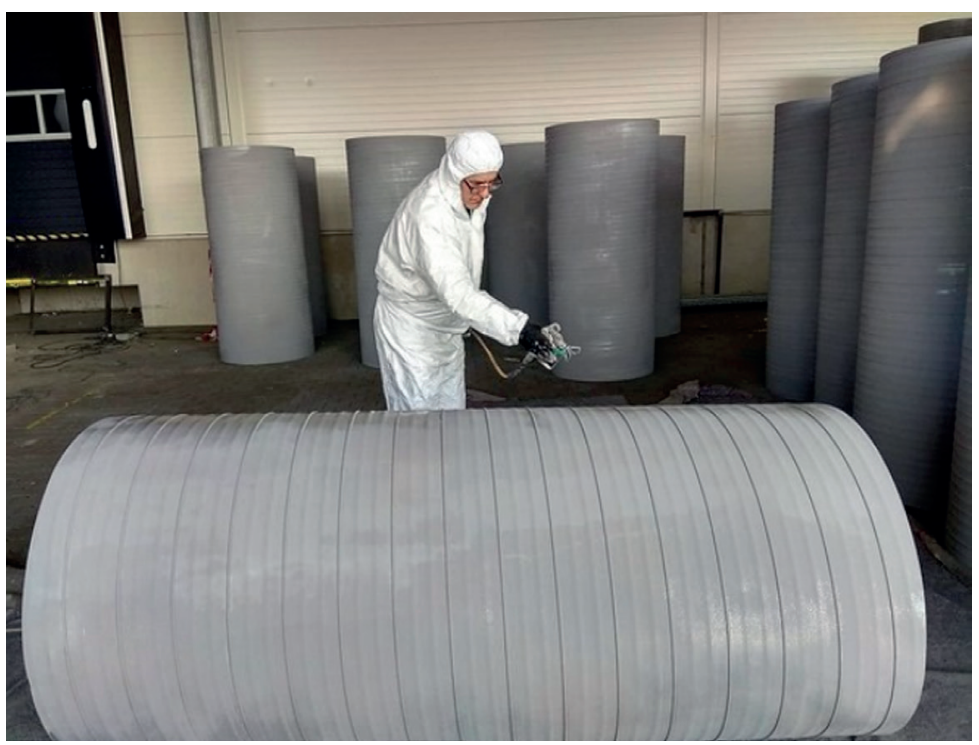

Fig.5. Application of thermal insulation from hollow glass-ceramic microspheres on ductwork (Source: photo archive of the Aditex, spol. s r. o., company) 


\section{Strategic goal of research}

The aim of this work will be to assess the potential of a new thin-film insulation material for technical distribution. The research project will evaluate whether thin-film insulation materials (mineral coatings / sprays), which are newly appearing on the market, can, in the future, be a quality alternative to already established insulation materials, which are more space-consuming and less adaptable in shape.

\section{Tactical targets}

- check the properties of the thin-film insulating material in relation to specific types of building installations by means of measurement;

- comparison of preselected quantities of thin-film insulating material with commonly used thermal insulations;

- enrichment of theoretical knowledge regarding findings on actually implemented projects (comparative measurements, case studies);

- evaluation of the knowledge gained from measurement and data collection related to energy consumption.

\section{Methodology}

In the first phase, the basic categorization of insulation materials took place according to their physical properties and thus the method of their use (distribution of internal water supply, heat, cold, air conditioning). The first phase will also include an analysis of existing empirical findings related to insulation materials. Currently, the first hypotheses are emerging, assuming the behaviour of various material insulation materials according to their use.

In the second phase, the range of investigated quantities is precisely selected for pre-selected representatives of individual categories of insulation materials, while not omitting the thin-film insulation for its comparison with commonly used insulation materials.

In the third phase, the methodology of measurement of selected quantities will be precisely specified according to their nature and, if possible, comparative laboratory measurements will be performed.

In the fourth phase of the research project, the hypotheses created in the first phase will be further enriched by possible practical usage and monitored on specific installations. The suitability of the design will be assessed, as an individual solution is expected from 
each installation. The research project will not be about creating tables where the given thickness corresponds to the given dimension, but it will be about monitoring specific cases. The aesthetics of the design and environmental impact will also be evaluated. Representatives of specific buildings with already established HVAC systems, for which the distribution of reconstruction has taken place, will be elected, and data related to energy consumption will be examined for these buildings. The research will focus on the difference between the variant before thermal insulation and after thermal insulation of the given distributions.

Finally, the potential use of insulating thin-film material in practice will be evaluated, where it is possible and where it makes sense to do so.

\section{Current state of research}

In the Czech Republic, cooperation was established with a company that develops, designs and applies insulating material from hollow glass-ceramic microspheres to technical installations.

The first phase of research is already complete, whilst the second and third phases are under development. The research project is based on the laboratory measurement of a specific material at the Technical and Testing Institute of Civil Engineering Prague SOE [7]. The cooperation was established with the University Centre for Energy Efficient Buildings of the Czech Technical University in Prague and the Faculty of Mechanical Engineering of the Czech Technical University in Prague. The conditions for specific laboratory measurements on a hot water tank and air-conditioning pipes are currently being agreed on.

\section{References}

[1] ČSN 755409 Vnitřní vodovody

[2] Vyhláška č. 193/2007 Sb. kterou se stanoví podrobnosti účinnosti užití energie při rozvodu tepelné energie a vnitřním rozvodu tepelné energie a chladu

[3] KAYNAKLI, O. Economic thermal insulation thickness for pipes and ducts: A review study. Renewable and Sustainable Energy Reviews [online]. 2014, 30, 184194 [cit. 2020-02-15]. DOI: 10.1016/j.rser.2013.09.026. ISSN 13640321. Dostupné z: https://linkinghub.elsevier.com/retrieve/pii/

[4] YALCIN, B. a S. AMOS. Characterization. Hollow Glass Microspheres for Plastics, Elastomers, and Adhe-sives Compounds. Elsevier, 2015, s. 7-34 DOI: 10.1016/B978-1-4557-7443-2.00002-5. ISBN 9781455774432.

[5] LIANG, J.Z. a F.H. LI. Heat transfer in polymer composites filled with inorga- 
nic hollow micro-spheres: A theo-retical model. Polymer Testing [online]. 2007, 26(8), 1025-1030 [cit. 2020-05-12]. DOI: 10.1016/j.polymertesting.2007.07.002. ISSN 01429418. Dostupné $\mathrm{z}$ : https://linkinghub.elsevier.com/retrieve/pii/ S0142941807001079

[6] KULESA, A.T. a M.J. ROBINSON. Analytical study of structural thermal insulating syntactic fo-ams. Composite Structures [online]. 2015, 119, 551-558 [cit. 2020-06-05]. DOI: 10.1016/j.compstruct.2014.09.025. ISSN 02638223. Dostupné z: https://linkinghub.elsevier.com/retrieve/pii/S0263822314004681

[7] Aditexs, spol. s.r.o. measuremets protocols 